Estonian Journal of Archaeology, 2005, 9, 2, 156-178

\title{
Villu Kadakas
}

\section{CONFUSION WITH THE "CHAPEL" WALLS IN THE SOUTHERN WING OF PADISE MONASTERY}

The ruin of the medieval Cistercian Padise monastery, some $50 \mathrm{~km} \mathrm{SW}$ of Tallinn has an outstanding position among the survived medieval buildings of Estonia. The monastic complex has developed during several building stages which are represented in complicated stratification. Six trial pits dug in rooms 2 and $2 \mathrm{a}$ in the southern wing during conservation works in 2003 gave results which contradict the recognized concept about the architectural development of the monastic complex. Rooms 2 and $2 \mathrm{a}$ have for decades been recognized as the earliest stage of the monastery: a chapel built in the 13th century by monks of Daugavgriva (Dünamünde) monastery. Several specialists have had their doubts about this hypothesis after debris was removed from room 2 in the 1990s. It is obvious from the fieldwork of 2003 that the walls of rooms 2 and 2a definitely do not belong to the earliest stage, but have been erected after demolishing some earlier stone buildings. Several circumstances still suggest as if the outer wall of the southern wing and the conventional quadrangle with its four wings were built after rooms 2 and 2a. This apparently insurmountable contradiction needs a new discussion about the development of the whole complex and especially the southern wing. First the complex of rooms 2 and $2 \mathrm{a}$, indisputably built as an architectural whole is described. Subsequently a solution is sought to the contradiction mentioned above which leads to a hypothesis about a gate once positioned in the southern wing. Finally the former function of the rooms on the main floor of the southern wing and of rooms 2 and $2 \mathrm{a}$ is discussed. The exceptional fortress-like nature of Padise monastery leads to rather exceptional hypotheses about the functions as well.

2003. aasta suvel konserveerimistööde käigus Padise kloostri lõunatiivas ruumis 2 kaevatud kuus šurfi andsid tulemusi, mis on vastuolus kehtiva ettekujutusega kloostrikompleksi ehituslikust kujunemisest. Ruume 2 ja 2a on aastakümneid peetud kogu kloostrikompleksi kõige varasemaks etapiks - 13. sajandil Daugavgrīva (Dünamünde) kloostri munkade rajatud kabeliks. Mitmel spetsialistil tekkisid kahtlused selle hüpoteesi suhtes 1990. aastatel. Pärast 2003. aasta välitöid oli selge, et ruumide 2 ja 2a müürid ei kuulu kindlasti kloostrikompleksi varaseimasse etappi, vaid on ilmselt rajatud alles pärast samal kohal asunud varasema kivihoonestuse lammutamist. Samas osutavad mitmed asjaolud jätkuvalt sellele, et kloostri lõunapoolne välismüür ja loogiliselt koos sellega terve nelja tiivaga põhikorpus on rajatud ruumide 2 ja 2a suhtes sekundaarsena. See näiliselt ületamatu vastuolu nõuab kogu kloostrikompleksi ja eriti lõunatiiva ehitusliku kujunemise uut lahtimõtestamist. Artiklis on kõigepealt kirjeldatud ruumidest 2 ja 2a koosnevat vaieldamatult ühtse arhitektuurilise tervikuna püstitatud ruumikompleksi. Järgnevalt on otsitud seletust eelnimetatud vastuolule, mis päädib hüpoteesiga lõunatiivas kunagi paiknenud väravakäigust. Lõpuks on arutletud klausuuri lõunatiiva peakorruse ruumide ja ruumide 2 ning 2 a võimalike funktsioonide üle. Padise kloostri erandlik kindluslik iseloom paneb otsima ka lõunatiiva ruumidele erandlikke funktsioone.

Villu Kadakas, OÜ Agu EMS, Roosikrantsi 17, 10119 Tallinn, Estonia; villuraator@hot.ee 


\section{Introduction}

The ruins of the medieval Padise monastery (Fig. 1) stand on the bank of River Kloostri (Fig. 2) ca $50 \mathrm{~km}$ south-west from Tallinn. This building complex of the fortified Cistercian Monastery is a rather well-preserved monument and has a remarkable position in the study of medieval architecture of Estonia (EAA $1965,168-172)$. Its walls partly hidden with collapsed debris have been mostly uncovered during conservation works in the second half of the 20th century. Most of the excavation work was done during the 1950s and 1960s and it was thoroughly monitored by Villem Raam - a renowned Estonian art historian. This work ceased at the beginning of the 1970s and the clearing in the southern wing ${ }^{1}$ remained unfinished.

Uncovering the former basement storey of the southern wing has been continued during the $1990 \mathrm{~s}$, and finally digging six trial pits in the room No. $2^{2}$ during

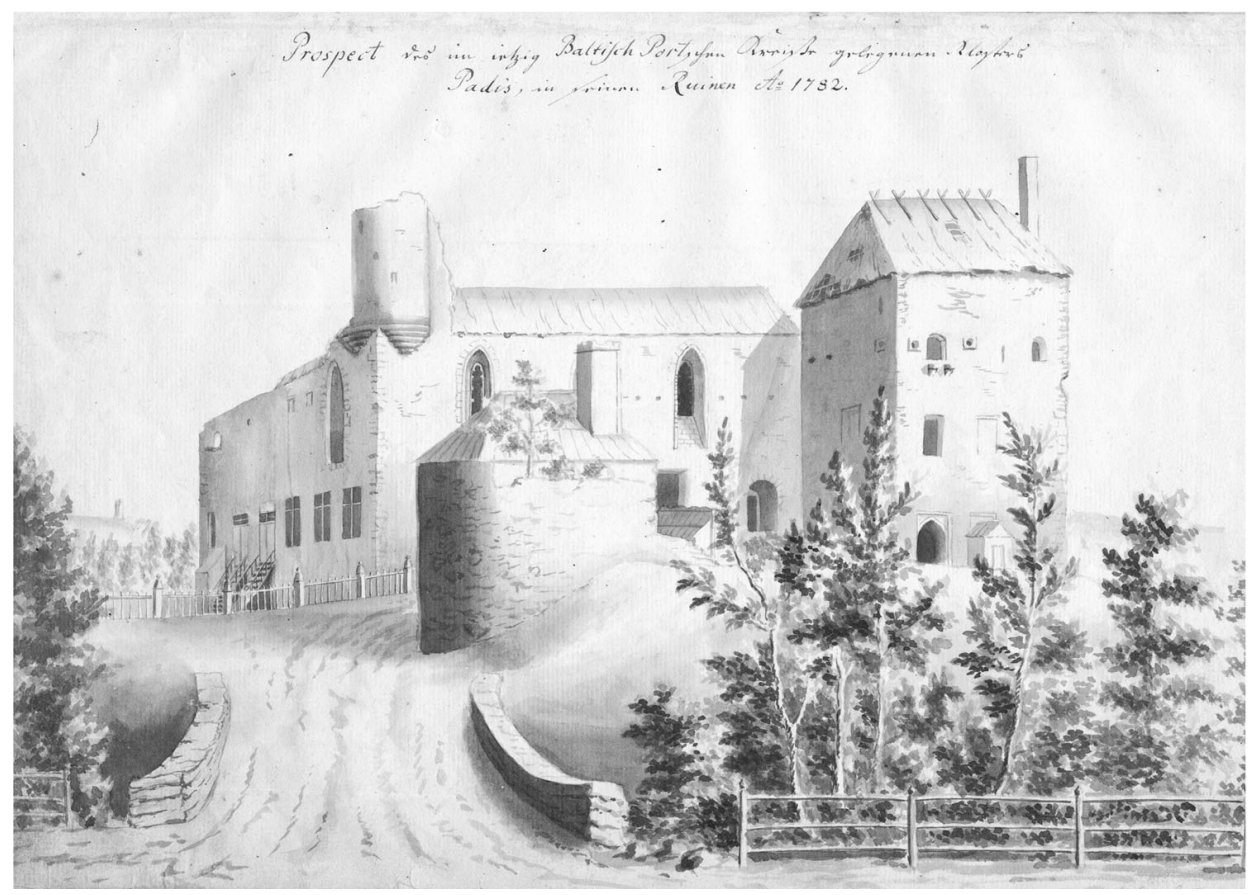

Fig. 1. View of the ruin from the road over the northern moat in 1782.

Joon 1. Vaade varemetele maanteelt üle põhjapoolse vallikraavi 1782. aastal (Latvijas Akademiska Biblioteka. Johann Christoph Brotze. Sammlung verschiedener Liefländischer Monumente).

1 The building is not exactly oriented according to the main directions of compass, but according to the natural defenses offered by the bank of the river. Still, the wings of Padise monastery have conventionally been referred to according to the closest main directions to avoid confusion.

2 To keep neutrality about the former function, the numbering of the rooms is presented according to the system applied by Villem Raam in his fieldwork reports and in Raam 1958. 


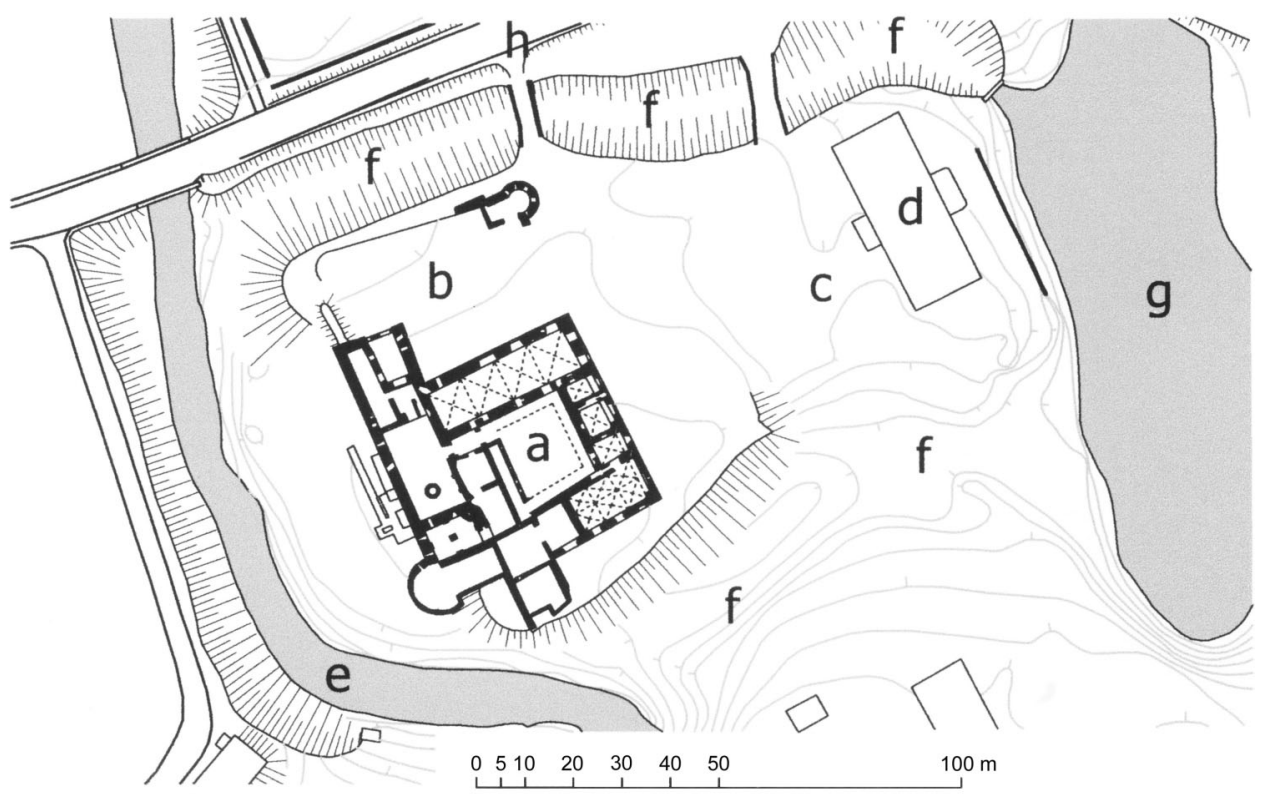

Fig. 2. Situation plan of Padise monastery. a ruin of the monastery, b northern bailey, c eastern bailey, $\mathrm{d}$ manor house from the 18th century, e River Kloostri, f former moat, g pond, $\mathrm{h}$ road.

Joon 2. Padise kloostri asendiplaan. a kloostri varemed, b põhjapoolne eeslinnus, c idapoolne eeslinnus, d mõisa härrastemaja 18. sajandil, e Kloostri jõgi, f endine vallikraav, g tiik, h maantee.

summer 2003 (see Kadakas \& Nilov 2004; Kadakas 2005) triggered the idea of the present paper. During the 1990s the debris in room 2 was removed down to the approximate obvious original floor level of the room although without detecting any remains of the floor itself. It was noticed that the demolition debris continues downwards from this obvious floor level which is more than 1 meter higher than the floors of the rest of the basement storey. The trial pits were dug in connection with conservation works of some crumbling parts of the walls with an additional intent to gain knowledge of some original floor level.

\section{History of Padise monastery}

The Padise region belonged in the 13th century to the Daugavgriva (Dünamünde) monastery situated near Riga (Schmidt 1941, 69). A chapel of unknown form and building material was mentioned in Padise in a record from 1281 referring to an argument between the monastery of Daugavgriva and the bishop of Tallinn (LUB III. 1857, No. 475a). The roots of the present building complex possibly go back to the middle of the 13th century, when according to a hypothesis by Villem Raam this chapel was built on the bank of the river in the area of the later 
southern wing of the conventional quadrangle (Raam 1997, 43). According to Raam the preserved walls of rooms 2 and 2a should constitute the lower parts of the chapel walls (Fig. 3). Although this room complex is not oriented according to the East-West axis as regular Christian churches and chapels, Raam arrived at this hypothesis by several decorated hewn limestone fragments of portals and a vault system, found in the debris filling these two rooms. These fragments have been dated to the mid-13th century (Raam 1997, 43). The two rooms will be described in detail later as one of the main targets of this paper.

The construction of the main buildings of the monastery did not probably start before 1305, when the buildings of Daugavgriva monastery were sold to the Livonian Order (Tuulse 1942, 275), and the monks subsequently had to move their headquarters to Padise. In 1317 the Danish king Erik Menved gave permission to build the monastery of stone which has been considered the real beginning of the Padise monastery (Schmidt 1941, 73). The consecration of the monastic church by the bishop of Tallinn was recorded in 1448 (Schmidt 1941, 101). The monastic complex was taken over by the Livonian Order in 1558, right after the beginning of the Livonian War (1558-1583), and then officially secularized in 1559 (Schmidt 1941, 118). During the war the buildings were used as a fortification by different armies and it suffered especially in the siege of 1580 when the Swedish army conquered it from Russian army. From 1622 the building belonged to the family von Ramm who rebuilt the church into their manorial residence (Fig. 1). Some other rooms were used for various economic purposes and the rest of the ruin as a quarry. The manorial residence was moved to a new house built east of the ruin in the end of the 18th century (Fig. 2) and the monastic complex was left in ruin.

According to Raam the original layout was a compact quadrangular body (the so called conventional quadrangle) with four wings around the central courtyard with the older chapel jutting out from the southern wing (Raam 1997, 43). The church constituted the northern wing. The final layout included a basement storey under all four wings including the church. There was an exceptional chapel for side altars under the eastern part of the church (Fig. 3). The communication between the wings of the basement storey and the main storey was performed through a two storey cloister (Fig. 6) around the courtyard. The eastern, southern and western wings all had a second storey, the rooms of which were accessed via separate staircases from the rooms of the main storey.

According to Raam the first period (1317-1343) ended with the uprising of St. George's Night when 28 monks were killed and the buildings set to fire. According to Raam the outer wall and the walls of the basement storey of the four wings were probably completed by that time. During the second period (ca 1375-1425) the building of the four wings was mostly completed with an outer wall, a crenelated battlement and the vaulted church. The third period (14251448) saw the completion of the refectory and the kitchen complex in the southern wing and an annex with a new gate tower and a new courtyard, the west bailey 
was added in front of the west wing as well. During the latter part of the Livonian War the building complex was held by Russian troops (1576-1580) who probably added some defenses (Raam 1997, 43).

\section{Rooms 2 and 2a: a 13th century chapel or something else?}

Even before digging the trial pits in room 2 it was obvious to all specialists Kaur Alttoa, Mart Keskküla and Jaan Tamm (Alttoa 2001, 15; see also Tamm $2002,40)$ - that the hypothesis of the 13th century chapel in rooms 2 and 2 a was improbable and most likely the rooms were of later origin and of some profane function. Alttoa has suggested a possibility that the monks of Daugavgriva had erected in Padise a filiation with an economic function: a grange of which rooms 2 and 2 a formed a part (Alttoa 2001, 15). The observations of Raam could now be easily complemented and modified as room 2 had been meanwhile emptied from debris down to the approximate original floor level of the room. The fieldwork of 1968 was so limited that Raam called his interpretations as "single fragmentary observations" (Raam 1969, 31). Thus it is most natural that the modifications of his conclusions do not come as a surprise.

Raam seems to have founded his hypothesis about the 13th century chapel mainly on two features. The first were the decorated hewn details found from debris filling rooms 2 and 2a. It can be easily overruled by the observation that none of the details has been found in the wall in its original place. They might have been used already as secondary building material in the upper walls of rooms 2 and $2 \mathrm{a}$ after demolishing the original 13 th century possible chapel, wherever it was. The standing remains of rooms 2 and 2a show no traces of any vaults. The second basis is the observation that the outer wall of the southern wing (consequently the whole quadrangular building complex!) has been erected against the eastern wall of rooms 2 and $2 \mathrm{a}$, both of the rooms having windows in this eastern wall opening inside room 3 of the southern wing. This aspect is hard to overcome by any other hypothesis, than the primality of rooms 2 and $2 \mathrm{a}$ to the whole southern wing but there is an alternative explanation as we will see below.

\section{Description of rooms 2 and $2 a$}

During digging the trial pits of 2003 the walls of room 2 were thoroughly recorded (Kadakas 2005, Figs. 3-6) and studied (Figs. 4-5). The most important modification to the observations of Raam was the discovery that the dividing wall between rooms 2 and $2 \mathrm{a}$ is not a secondary addition to the outer walls, but is built together with the latter (Kadakas 2005, 14). It obviously undoes the whole concept of the originally single long room in place of present rooms 2 and 2 a. Consequently there have always been two rooms. It is still possible that a single room was on the main floor above but nothing has preserved of it. 


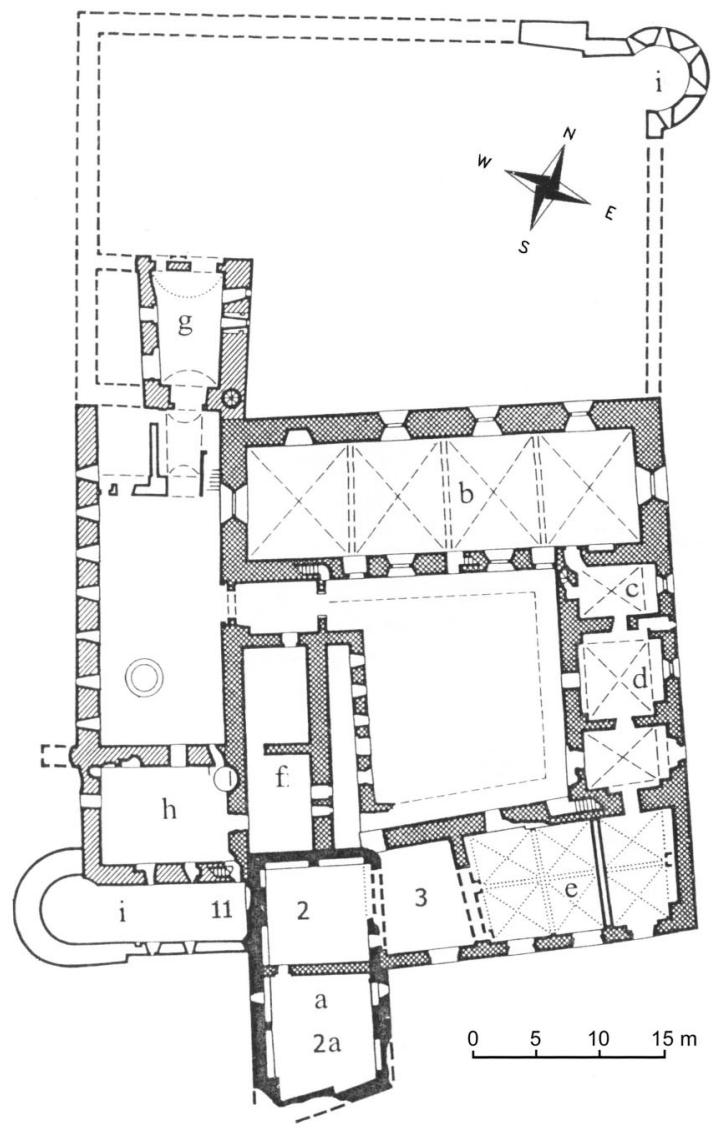

Fig. 3. Building stages of Padise monastery by Raam. a chapel, b church, c sacristy, d chapter house, e refectory, f cellar with the well, $g$ tower of the front gate, $h$ defense and dwelling tower, $i$ arquebus towers, 2, 2a, 3, 11 room numbers in the article.

Joon 3. Padise kloostri ehitusetapid Raami järgi. a kabel, b kirik, c käärkamber, d kapiitlisaal, e refektoorium, f kaevukelder, g eesvärava torn, h kaitse- ja elutorn, i haakpüssitornid, 2, 2a, 3, 11 ruumide numbrid artiklis.

The two "twin" rooms are almost identical with the symmetry axis running along the dividing wall. The single exception is that the southern wall of room $2 \mathrm{a}$ does not run perpendicularly to the other walls. The architect has still managed to "amend" this derivation from symmetry in the interior by planning the inner face of the south wall with the arches of the wall niches perpendicularly with other walls, as Raam noticed in 1969 (Raam 1969, 33). The most important features of the two rooms are the arched wall niches (Figs. 5-6) running all along the inner faces of the outer walls. As he noted (Raam 1969, 30-31) these niches do not constitute just some random wall cabinets or room sparing recesses for benches, but they are composed in a strict cycle and form. 


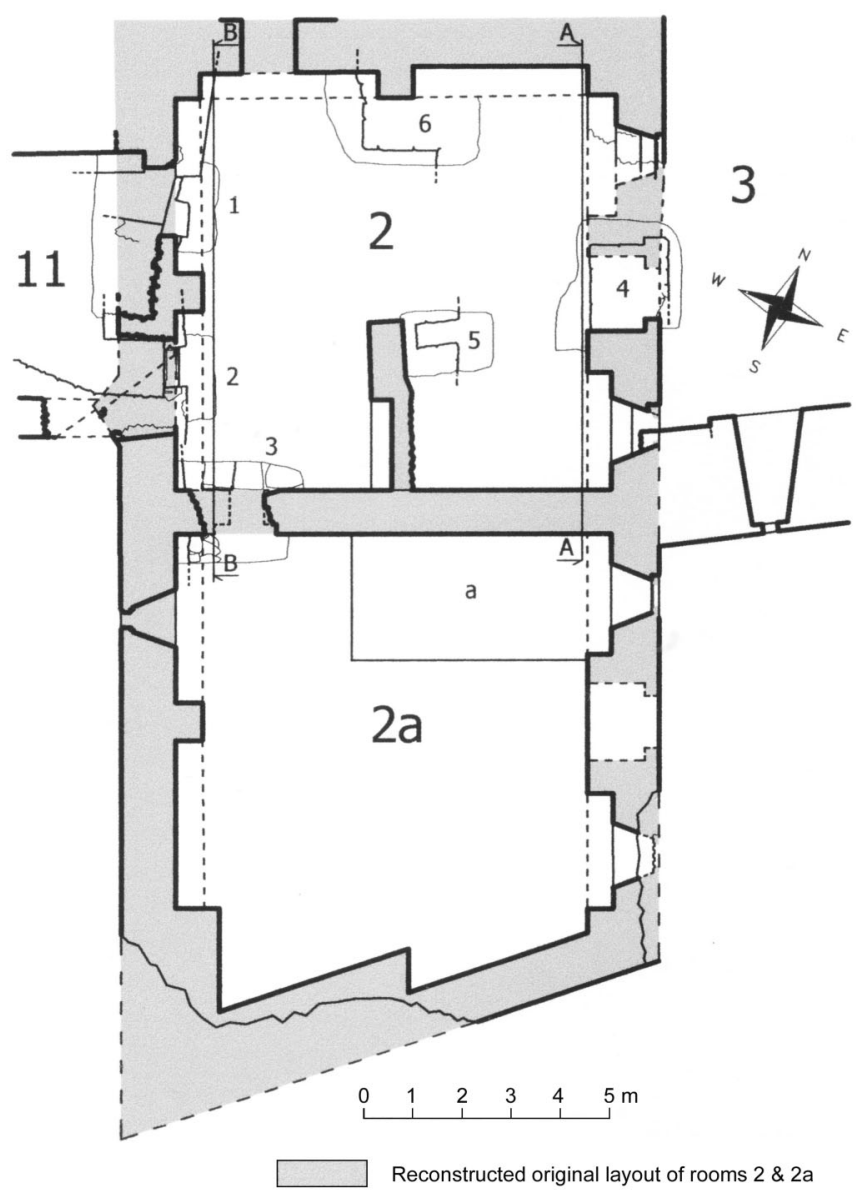

Fig. 4. Plan of rooms 2 and 2a. a hypocaust slab, 1-6 numbers of test pits, 2, 2a, 3, 11 room numbers, A-A, B-B sections Fig. 5.

Joon 4. Ruumide 2 ja 2a plaan. a hüpokausti plaat, 1-6 šurfide numbrid, 2, 2a, 3, 11 ruumide numbrid, A-A, B-B lõiked joon 5.

The niches in the northern wall of room 2 , in the western wall of both rooms and the southern wall of room $2 \mathrm{a}$ are wider than the ones in the eastern walls. The preserved niches in the northern and western walls suggest they were all covered with a round arch (Raam 1969, 31). All these walls described above have two niches alongside and no doorways. The eastern walls have both had two niches as well but they are narrower because of the doorway in the middle of the wall (Fig. 5: section A-A). Those narrow niches had got low segment arches instead of round ones. The two doorways have had simple hewn limestone jambs according to the preserved fragment in room 2 . The form of the portal arch is not known. 


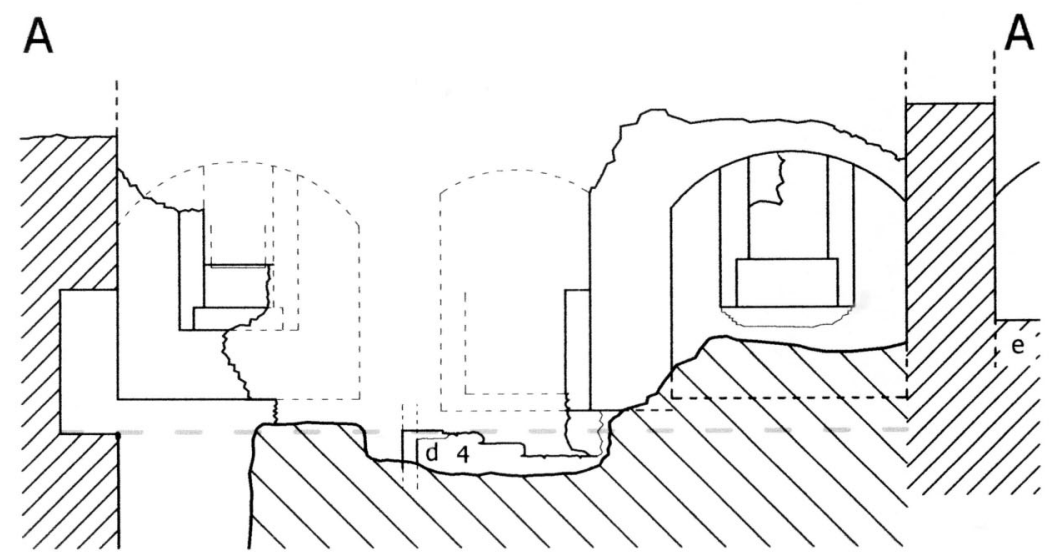

B

B

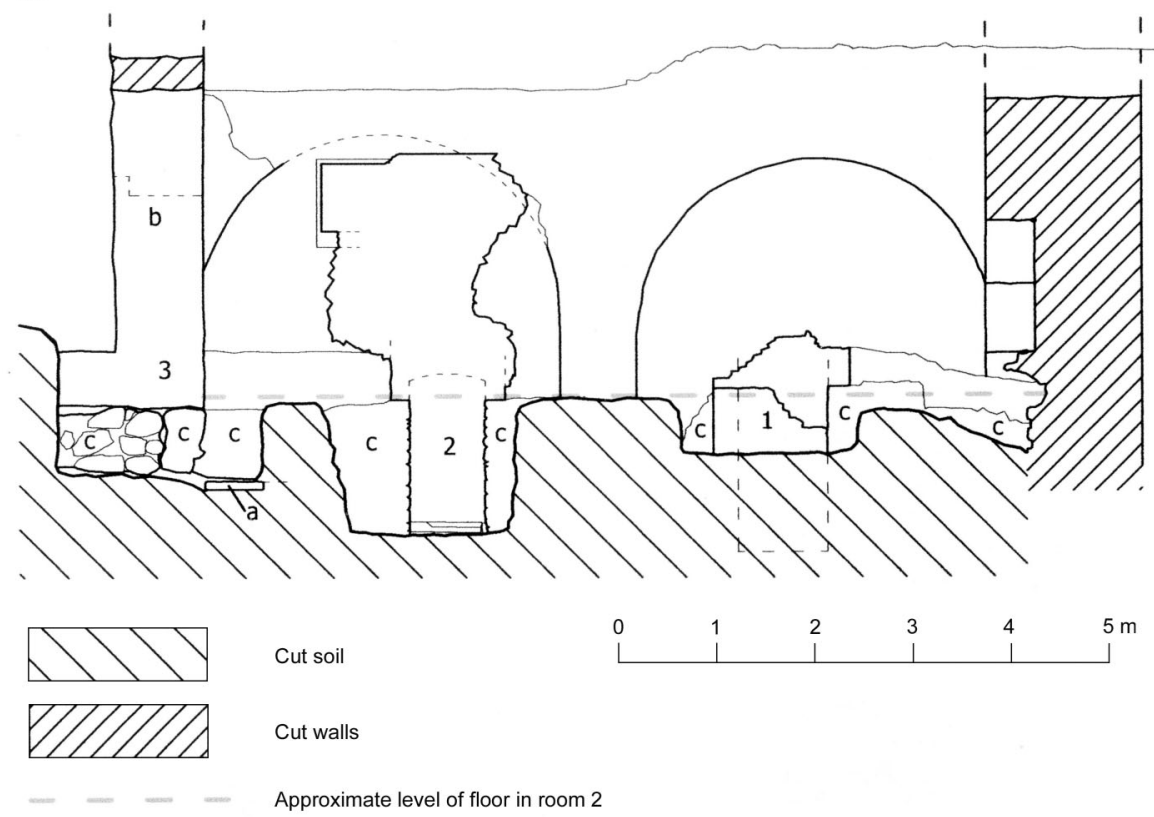

Fig. 5. Section A-A and B-B. a floor fragment of limestone slabs, b position of the doorway in the dividing wall, c remains of an earlier wall with two doorways under western wall of room 2, $\mathrm{d}$ remains of an earlier portal under eastern wall of room 2, e hypocaust slab, 1-4 numbers of test pits.

Joon 5. Lõige A-A ja B-B. a paeplaatidest põranda katke, b ukseava asend vaheseinas, c varasema seina jäänused koos kahe ukseavaga ruumi 2 lääneseina all, $d$ varasema portaali jäänused ruumi idaseina all, e hüpokausti plaat, 1-4 šurfide numbrid. 


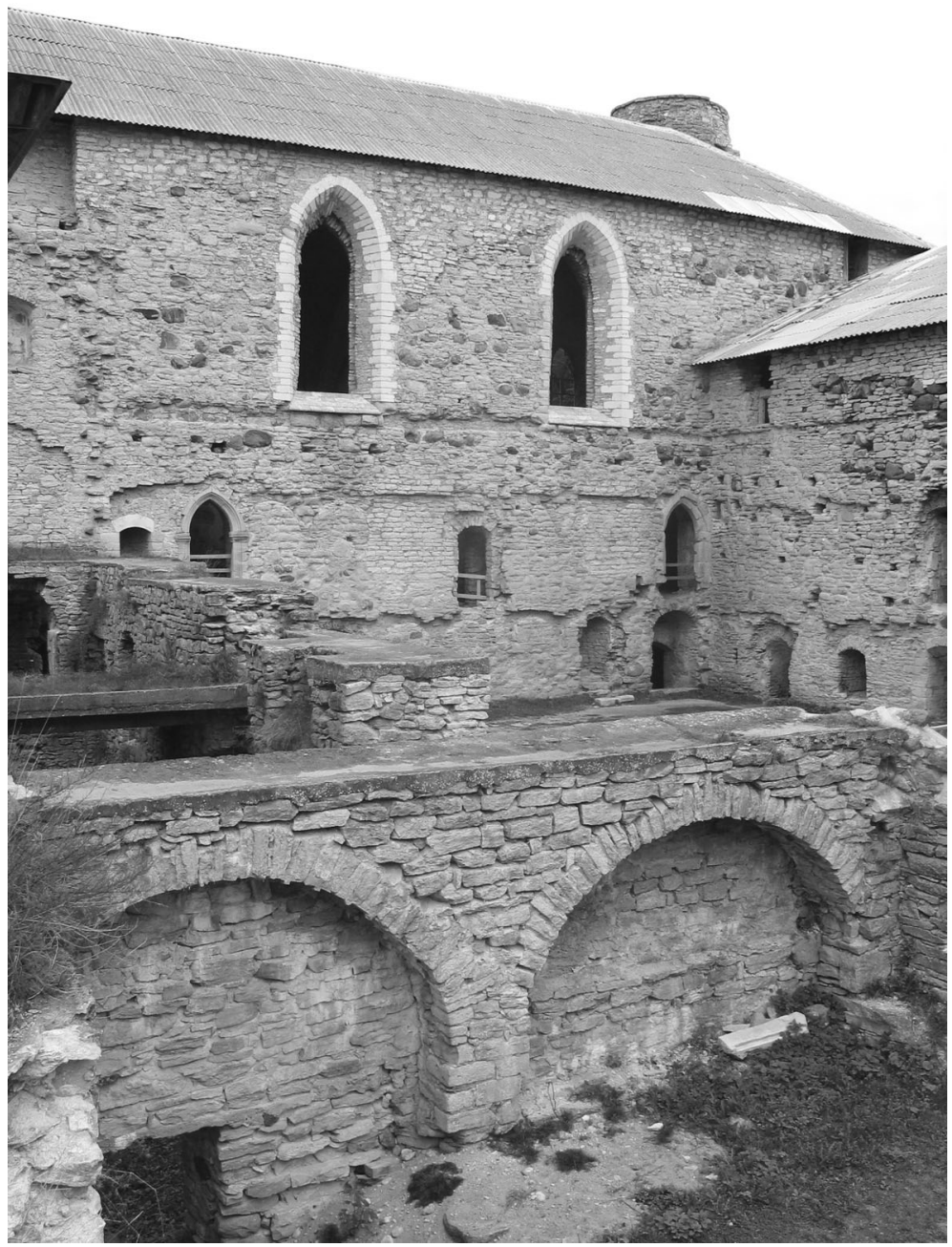

Fig. 6. View from room 2 to northeast. Foreground: reconstructed north wall of room 2. Background: south exterior of the church with traces of the two-storey cloister.

Joon 6. Vaade ruumist 2 kirde suunas. Esiplaanil: ruumi 2 põhjasein. Tagaplaanil: kiriku lõunasein kahekorruselise ristikäigu jälgedega.

All the niches of the eastern wall have had small window openings. According to a photograph from 1969 (Raam 1970, photo 16) the hewn jamb of the northern window (now crumbled) in room 2 has been inserted as a later addition, but the large vent of the window itself looks primal. The southern niche of the western wall has had a window turned astray to fit with the southern wall of room 11 . The northern niche of the western wall of room $2 \mathrm{a}$ has had a similar but perpendicularly positioned window. Raam has suggested that the windows in the eastern wall are original, but the windows of the western wall secondarily 
inserted additions (Raam 1969, 27). By now the latter have crumbled almost to nothing and the problem cannot be studied. One has to rely on the observations of Raam and take it for granted that the eastern windows were original but the western ones were not.

Raam detected a fragmented hewn slab with openings for hot air and a vault of a hypocaust stove (Fig. 4) in the northeastern corner of room 2a (Raam 1969, 27). It has not been studied further but the trial pit No. 5 in room 2 revealed remains of some underground stove as well (Kadakas 2005, 17). This stove has been connected with the fragment of a dividing wall which position corresponds to the western edge of the slab in room 2a. It enables to conclude that the two rooms probably shared a common heating system of a hypocaust type around the eastern end of the dividing wall. The details of this heating system still remain vague. There was a doorway in the western part of the dividing wall (in place of test pit 3) preserved in the 1960s but it had totally fallen apart by 2003 . A photograph from 1969 (Raam 1969, photo 51) gives a hint that the doorway was a secondary breakthrough, but this aspect was not clearly recorded as no one probably expected it to decay in a few decades. The fact that the jambs of the doorway have utterly broken away like a filling suggests it was indeed a secondary breakthrough.

Raam has concluded that rooms 2 and 2 a once formed an architectural whole and it is difficult to associate it with the composition of the rest of Padise building complex because of its placement in the whole plan and its architectural characteristics (Raam 1969, 26). This is so indeed, although there have been two separate rooms from the beginning.

\section{Stratigraphic context of rooms 2 and $2 a$}

The fieldwork of 2003 offered several intriguing results as to the stratigraphic relations of the twin rooms to the neighbouring parts of the monastery. The trial pits of 2003 offered a surprising conclusion: the walls of the twin rooms have been erected after demolishing some earlier stone buildings down to the approximate floor level of the rooms. Data from trial pit No. 3 suggest that the dividing wall and the western wall of room 2 have been erected together just on top of some earlier wall fragments on the same spot. Pits 1 and 2 presented two simple abandoned doorways through an earlier wall directly under the later western wall of room 2 (Fig. 5: section B-B). The sills of these doorways suggest the corresponding floor level was even some $150 \mathrm{~cm}$ below the approximate floor level of room 2. A floor of unworked limestone slabs directly on natural ground was detected in pit 3 some $80 \mathrm{~cm}$ below the approximate floor level of room 2 . In room 2a the results of pit 3 affirmed Raam's conclusion (Raam 1970, 3-4) that the room together with its outer walls had been built on natural ground.

Pit 4 was dug under the doorway of room 2 expecting to find a contemporary sill. Instead, the pit presented a fragment of an earlier wall with one jamb of a 
hewn portal (Fig. 5: section A-A). Obviously the discovered portal belongs to an earlier building than room 2 , the eastern wall of which has been erected almost exactly on top of it. Pit 6 revealed a quite incomprehensible fragment of an earlier wall. The stove found in pit 5 can be connected with the heating system of room 2 itself than with any earlier building.

It can be concluded that the walls of rooms 2 and $2 \mathrm{a}$ were erected on top of some previously demolished building in the area of room 2 . Consequently it is not possible to talk about rooms 2 and $2 \mathrm{a}$ as the earliest stage of the monastic complex any more, whatever their original function could have been. The development of Padise monastery has so far been described as a simple cumulative sequence of only positive events, i.e. erecting and adding new parts without any significant demolishing activities. It is most natural that especially archaeologists introduce the concept of extensive demolishing activities during the Middle Ages, as the concept of negative stratigraphic units has been developed in archaeology (Harris 1979).

It is theoretically possible to debate about a broken building project by the earlier wall fragments found in the pits, but in this case the diversity and variety of those fragments make such explanation less probable. At the same time it is theoretically possible to interpret the earlier wall fragments as a contemporary basement storey under room 2 as planned and once existed together. If this is true, such basement storey must have been exceptionally low with its ca $150 \ldots 160 \mathrm{~cm}$ as all other basement rooms in Padise are considerably higher. It would be quite hard to speak about a basement storey in the area of pit 3 by the slab floor ca $80 \mathrm{~cm}$ below the floor level of room 2 . The controversy of the floor levels in pits 2 and 3 hardly $1 \mathrm{~m}$ apart of each other has no easy explanation. Anyway, the idea of the contemporary basement seems difficult to accept.

By trying to understand the role of rooms 2 and 2a in the Padise monastery it is important to discuss the original layout and possible function of the rooms found under the walls of room 2, i.e. whether they are earlier or a contemporary basement storey.

The doorways under the western wall of room 2 indicate that room 11 must have existed in some form before erecting rooms 2 and 2a. The niches of the doorways are situated in room 11. It was not possible to determine if the doorways were originally built with this wall or as later insertions. The wall fragments in pit 3 under the western wall of room 2 and the dividing wall can be interpreted as the original outer corner of the southern and western wings of the quadrangular main body. An additional test pit on the outside of the western wall of rooms 2 and 2 a could bring clarity into this matter.

It is hard to determine the stratigraphic relations of the northern wall of room 2 with the rooms of the western wing immediately north of it because it has been largely replaced during the restoration works of the 1960s (Fig. 6). It can be supposed by the wall fragment found in pit 6 that it could belong to the original eastern wall of the western wing extending southwards. There are some indications that the western cloister might have originally reached southwards into the area of room 2 as well. If this be true, the wall fragment with a portal found in test pit 
5 might have belonged to this originally extended western cloister. Anyway, the wall fragment in pit 6 indicates that there was rather a set of at least two rooms than one single room under later room 2.

The stratigraphic relations of the twin rooms to the outer wall of the southern wing and room 3 were obvious long before the fieldwork of 2003 as mentioned above. There is a visible vertical joist on the outer side of the outer wall of the southern wing separating it from the eastern wall of the twin rooms. The two windows in the eastern wall of room 2 obviously indicate that there must have originally been some open space instead of room 3 .

The stratigraphic relations of the twin rooms can be concluded as follows:

- the twin rooms were erected after demolishing some former room complex in the area of room 2 (possibly some rooms in the southwestern corner of the conventional quadrangle, the corner itself and the extension of the western cloister) and room 11,

- the twin rooms were erected before building the outer wall of the southern wing and before the formation of room 3 as we know it.

\section{Controversy of rooms 2 and 2a concerning the known building history of the conventional quadrangle}

From the last observation Raam has concluded that rooms 2 and 2a formed an earlier building than the whole conventional quadrangle. This conclusion is most logical and calls forth no objections. But combining this conclusion with the results of 2003 forces a most controversial conclusion, which is hard to link with the recorded history of the monastery or any interpretations. We would have a set of rooms 2 and $2 \mathrm{a}$, without apparent function, predating the whole conventional quadrangle and at the same time being built after demolition of some earlier buildings without clearly known extent and apparent function. The idea of a grange predating the monastery (see Alttoa 2001, 15) is a most logical explanation but at the same time it is possible to suspect some fallacy in the chain of observations and conclusions analysing the physical substance.

While re-examining earlier studies the first suggestion of a buildings archaeologist would be that some interface between stratigraphic units has not been noticed, i.e. some two units have not been differentiated. In other words, there is reason to suspect that a theoretical concept about the formation of the building has overruled the detailed study of the stratification of physical substance. First I would turn to the largest unit in the game, the outer wall of the conventional quadrangle.

There has been no doubt that up to the level of the arches of the windows of the church the lower part of the outer wall has been erected during one period, the 1st period according to Raam (Raam 1997, 43). On the main floor the inner face of the outer wall in both the eastern and southern wings has been equipped with round arches at least $4 \mathrm{~m}$ wide between plain rectangular buttresses (Fig. 3), 
features quite similar to rooms 2 and 2a. These have survived in the eastern wing with the inner walls built later against the buttresses. In the southern wing in the big room in the southeast corner the arches were demolished and the buttresses replaced by slender hewn limestone pilasters. These observations confirm the unity of the outer walls. Only room 3 of the southern wing shows traces of two much narrower arches, although much masonry on both faces of the wall has been replaced during conservation works.

The outer wall in the area of room 3 (Fig. 7) shows more irregularities on both upper floors. The outer wall on the 2nd floor is considerably thinner than the rest of outer walls of the 2 nd floor in the southern and eastern wings and built in a different manner using alternating horizontal rows of limestone and rubble, now partly replaced during conservation. The southwestern corner of room 3 on the first and the second floor has been built as if the southern wing did not continue further towards west. This corner is built of small limestone rubble, i.e. in a clearly different manner than the outer corners of the rectangular main complex. The latter are erected of large hewn limestone quoins. The inner face of room 3 and probably the whole southern wing on the basement storey is mostly covered with secondary coating masonry and therefore cannot be analysed concerning this

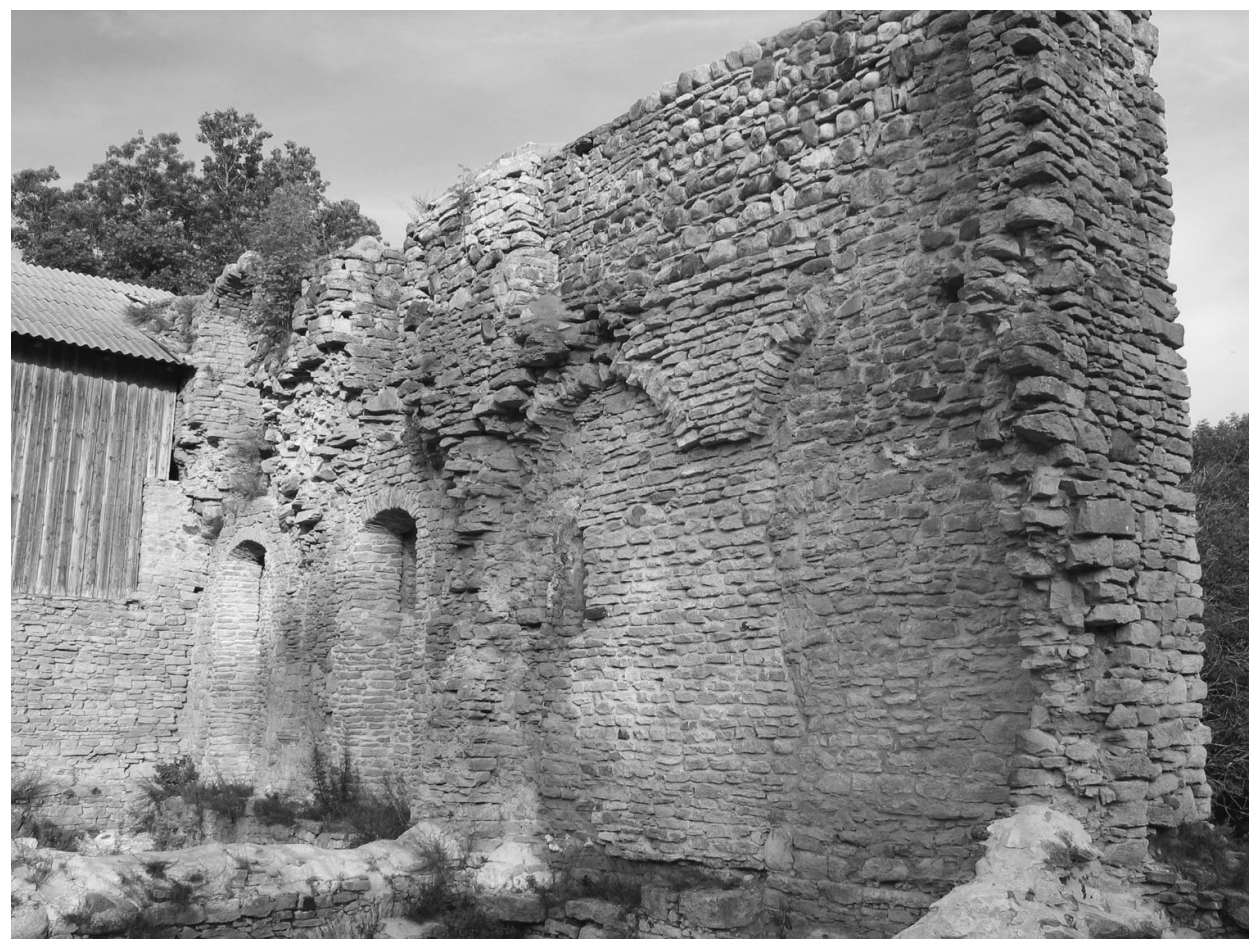

Fig. 7. Inside of the outer wall of the main storey of the southern wing.

Joon 7. Lõunatiiva peakorruse välisseina sisekülg. 
matter. The outer face of the basement storey of the whole southern wing is partly hidden underground and has partly been replaced during conservation. Thus it is almost impossible to gain information about the original layout of the outer wall in the level of the basement storey. The eastern wall of room 3 has been positioned astray to other walls without apparent reason.

These observations can be summed as follows: the outer wall of the southern wing in room 3 has probably been thoroughly reconstructed at some undetermined time, changing its original layout beyond recognition. Consequently it might not be the original outer wall of the main rectangular complex which reaches the eastern wall of rooms 2 and 2a but the masonry of the later reconstruction. Thus an alternative explanation to the controversy can be provided: the outer wall of the southern wing did not originally reach the eastern wall of rooms 2 and 2 a. Possibly the southern wing did not originally even include the area of room 3 .

There must have been a reason for the outer wall not to reach rooms 2 and $2 \mathrm{a}$. A logical reason for this would be that there might have been a planned gap between the original outer wall of the southern wing and the twin rooms. Such a gap would mean a gateway in the area of later room 3. A gateway would explain the windows in the eastern wall of room 2.

\section{A southern gateway - discussing the hypothesis}

Looking at the plan of the monastery (Fig. 2) one can notice that the building complex has been positioned very closely to the steep bank of the river on the southwestern side and the southern corner. The same applies to the wall of the northern outer bailey following the moat a few metres away. The moat near the eastern wing of the main body cannot be observed because it has probably been filled if it ever existed in that place. Only the moat near the southern wing has been positioned along the southern wall of room 2 a running eastwards at least 7 metres away from the wall of the southern wing. This circumstance puzzled Raam enough so that he dug a trench from the eastern corner of the main body to the bottom of the moat. The results indicated that the moat had never been closer to the southern wing leaving a plateau between the southern wing and the moat. He concluded that the original defences of the monastery might have been located near the bank of the moat away from the later southern wing (Raam 1970, 7), although he did not find any foundation on the edge of the plateau.

The plateau between the southern wing and the moat can be easily explained by a gateway in the area of room 3. In this case it must have been necessary for the road to pass the eastern corner of the main rectangular complex to reach the gateway. The distance between the corner and the original slope of the moat was approximately $7 \mathrm{~m}$ (Raam 1970, 9-14), just suitable for an additional gateway which might have once existed there. The western gateway of the rectangular main complex has been originally positioned the same way leaving a plateau between the main complex and the river where the western outer bailey was built 
later during the 3rd period. The gate was "hidden" by such a narrow plateau from a direct attack.

Why an extra gateway for the main rectangular complex if there was one planned in the western wing already? As Padise monastery was built as a fortress, it did not apparently possess an exit for monks in the eastern wing as would be normal in a Cistercian monastery (Leroux-Dhuys 1998, 67). Thus a southern exit could have served for this instead. The southern exit need not have been a wide gate for carts and provided with portcullis as the western gate, but a modest exit for pedestrians. There might have been additional reasons for the existence of the southern gate. The junction of the river and the moat south of the monastery would be the single point where water could be dammed up if water was needed in the moat running east of the monastery. Guessing further, it would be logical to position a water-wheel near such a dam. It should be remembered that the position of the medieval water-mill as well as the road passing the monastery is not known, although it is obvious that both existed somewhere.

A dam for the water-mill and flooding the moat would be a suitable place for positioning a bridge over the river as well. Directing the road close by the gate or even through the outer bailey would afford control over traffic. It would give an obvious advantage during a siege as the bridge could be closed for any traffic or even demolished with ease. A harbour, hardly for seafaring vessels, but at least for small boats could have been positioned on the eastern bank of the river near the building, defended by two gateways. Anyway, maintaining a dam, water-mill or a bridge would all need an easy access from the monastery, giving reason for a southern gate. It should be remembered that Padise was a fortress where several profane buildings which normally would be scattered on a large territory could have been clustered to a regular conventional quadrangle.

Such a southern gate could have existed already before building rooms 2 and 2a. The earlier portal found in pit 4 could have opened to the same gateway. The southern gate would have finally become useless by erecting the eastern bailey which probably incorporated the small plateau near the southern wing. Then a new exit might have been cut into the eastern wing. Making this eastern bailey has been ascribed to the short Russian occupation during the Livonian War (Raam 1997, 44). As nothing of it stands above ground and the underground has not been investigated, it cannot be excluded that the eastern bailey is of earlier origin.

\section{Function of rooms on the main storey of the southern wing}

First it should be emphasized that the layout of Padise monastery is not of a most typical Cistercian monastery according to the strict building rules of the Order. Padise monastery has been literally a compact fortress where some compromises with the rules were indispensable (see also Raam 1992, 46). It especially concerns the southern wing where according to the rules typically two 
separate refectories for the monks and lay brethren were positioned perpendicularly to the southern cloister (Leroux-Dhuys 1998, 71; Schneider et al. 1977, 69). The fortress nature of Padise monastery has required a compression of protruding buildings. This is probably why there is no protruding chancel with chapels in the eastern part of the church (Raam 1992, 47-48). At the same time it was probably necessary to distribute some rooms which usually should be laid out on the main storey between different storeys. Rooms 2 and 2 a conveniently form the single protruding building in the southern wing of Padise monastery. Thus it is easiest to assume that there was a refectory, either for monks or the lay brethren on the main storey above the rooms 2 and 2 a. Unfortunately nothing has survived of the main storey here. The room probably had its entrance in the junction of the western and southern cloister.

Raam interpreted the big room in the south-eastern corner of the quadrangle as the monks' refectory (Raam 1958, 17; 1997, 44) probably because he had reserved the place above rooms 2 and $2 \mathrm{a}$ for the chapel. This big room in southeast would be suitable as the monks' day room because of its position in the southeast corner of the conventional quadrangle, although monks' day room was typically positioned perpendicularly as well (Leroux-Dhuys 1998, 67). The wide segmented arched windows in the southern wall affording the best illumination in the whole monastic complex fully support this idea, because among other activities, copying the books typically took place in the monks' day room (Leroux-Dhuys 1998, 67). This south-eastern room was heated by a hypocaust stove underneath. In Estonian cold climate several rooms of the monastery had to be heated and there is probably no point in associating this heating system with the specific calefactorium (the warming room), although a typical position of a calefactorium would be somewhere in the middle of the southern wing close to the kitchen and refectory (Leroux-Dhuys 1998, 67; Schneider et al. 1977, 69). Thus there was probably no reason to build a separate calefactorium in Padise as the monks' day room had to be heated anyway. Room 3 area on the main floor above the supposed southern gate between room 2 and the supposed monks' day room was a separate room.

There are probably no good reasons to search for the specific refectory of the lay brothers or conversi in Padise monastery in its typical place and position - an oblong room positioned perpendicularly to the southern cloister in the southwestern corner of the conventional quadrangle (Leroux-Dhuys 1998; Schneider et al. 1977, 69). The refectory of the conversi was specifically in German Cistercian monasteries close to the church (Schneider et al. 1977, 68), often not in the southwestern corner of the quadrangle. By the 14th century the number of lay brothers in Cistercian monasteries had diminished drastically (Schneider et al. 1977, 50). At those times it was common to even turn the former rooms of the lay brothers over to other uses, e.g. a guesthouse, a winter refectory, an abbot's lodgings, a library or even a simple grange (Leroux-Dhuys 1998, 75; Schneider et al. 1977, 68). For this reason there is basis to suspect that the lay brothers were not paid much attention to 
while planning the special organization of Padise conventional quadrangle. There might have been a few small rooms planned for the use of the small number of staying or visiting lay brothers in the western wing and the western tower. This is why there is only one building part, only one refectory positioned perpendicularly towards the southern cloister as there was probably no need for a separate big room for the lay brothers' refectory in the 14th century.

The western wing, typically housing the lay brothers, is notably small in Padise compared to the other wings. The main floor of the west wing probably consisted of two oblong rooms of similar dimensions plus the gateway. There are remains of a wide chimney in the southern room and a hypocaust stove in the northern room of the basement storey. It would be logical to suppose a kitchen in the southern room of the main floor as it could have been easily connected with the supposed monks' refectory above rooms 2 and 2 a by a doorway or by a serving hatch.

\section{Function of rooms 2 and $2 a$}

Finally there is the function of rooms 2 and $2 \mathrm{a}$ to discuss. All the rooms of the basement storey look rather mundane and were probably of some economic function, e.g. storerooms. The only exceptions are the chapel under the eastern part of the church and rooms 2 and 2a. Therefore some more elaborate function than a simple storeroom should be sought. The heating system mentioned above suggests that the rooms were both heatable and probably residential.

The most peculiar feature is the accessibility of the rooms. With or without the southern gateway, it is clear that after building the southern wing room 2 could be accessed from inside the fortified quadrangle and room 2 a from outside. Leaving the access to one dwelling room outside the main monastic complex, supplying it only with a modest undefended doorway, is a most significant feature. Vicinity of the supposed gateway could hint to a room for a gate-warden. He had to have his office somewhere but naturally outside the monks' area as all the lay people would. The only doors of both rooms leading to the supposed gateway that possibly could be closed from both ends, would indicate a sort of seclusion from the monks' area. More probably the gate-warden was positioned at the gate in the western wing or near the exit of the outer bailey at the times when it existed already. The supposed south gateway would have led directly and only to the secluded monks' area not suitable for accepting visitors.

At the same time the intentional identity of the two rooms, one positioned outside and one inside the main complex, points to a more complicated ideology behind it. The two rooms seem to be intentionally with identical layout and function, but at the same time with somewhat "unequal" position. The existing concept of the Padise monastery does not include the visitors' quarters, but it is clear that it had to exist somewhere. Usually the guesthouse, beyond doubt existing in every Cistercian monastery, was positioned close to the outermost exit of 
the monastic territory far away from the monks' area (Leroux-Dhuys 1998, 49; Schneider et al. 1977, 72). The fortress nature of Padise might have necessitated an exception in this matter to keep at least the important guests in the fortified area, not far from the entrance of the symbolic enclosure. The importance of the guesthouse cannot be underestimated because it was listed among the very first buildings to be erected immediately in a newly established monastery, namely the oratory, the refectory, the dormitory and the gatehouse, "so that they may, as soon as they arrive at the place, serve God and live according to the Rule" (Leroux-Dhuys 1998, 49; Schneider et al. 1977, 27). The position and the nature of guesthouses do not seem to have been paid much attention to in literature concerning Cistercian monasteries, probably because of its typically marginal placement far off the conventional quadrangle.

The twin rooms would suit for the accommodating high-ranking visitors. For example, inner room 2 could have been kept for a clerical guest (a bishop or an abbot of the mother abbey) and the outer room 2a for a secular guest to "equally" meet the demands of both the clerical and the secular lord who could be visiting the monastery at the same time at some important event. In this manner the secular guest could have been suitably kept staying overnight outside the conventional border of the monks' area, which possibly ran along the outer wall of the main rectangular complex. At the same time equal services could be provided for both guests and the identity of the rooms provided somewhat "equal" status for both. Naturally other explanations could be possible for the function of the twin rooms.

I would say nothing specific about the absolute dates of the observed and supposed building stages introduced above as there is not sufficient data and most of the ideas presented are hypothetical. It is even difficult to connect the described rebuilding activities with the development stages presented by Raam. The only thing quite certain is that the building of the twin rooms probably took place in the monastery period before the Livonian War and not later. Closing the supposed gate (if it ever existed) might have happened later, e.g. among the various fortification activities during the Livonian War. The discussion about the functions of rooms presented here rather deals with the final layout of the monastery right before the Livonian War, not with its development.

Every fieldwork typically rises more questions than it can answer. The fieldwork of 2003 in Padise added a few features which can be treated as facts. This little increase of knowledge offers a possibility to play a game using ascertained stratigraphic sequences, generally accepted concepts and logical suppositions. Everyone does it using his "tools" and background knowledge and it leads to results which naturally differ more or less from each other. Future field studies and restudy of old fieldwork reports would certainly answer many questions including the problems around the twin rooms and the supposed gate. Many problems including the original function of the twin rooms will probably not find a definite answer but will remain a matter of discussion. I hope there will be discussion. 


\section{Acknowledgements}

Special thanks to Kaur Alttoa, Mart Keskküla and Jaan Tamm for consultations during the field work.

\section{References}

Alttoa, K. 2001. Einige Beispiele der Kombinationen von Burg und Kirche in Estland. - Castella Maris Baltici, 3-4. Turku, 11-17.

EAA 1965 = Eesti arhitektuuri ajalugu. Tallinn.

Harris, E. C. 1979. Principles of Archaeological Stratigraphy. London.

Kadakas, V. 2005. Arheoloogilised uuringud Padise kloostri varemetes (reg-nr 2921) aastal 2003 ruumide 2 ja 2 a piirkonnas. Manuscript in the National Heritage Board. Tallinn.

Kadakas, V. \& Nilov, H. 2004. Various investigations in Tallinn and Harjumaa. - AVE, 2003, $160-175$.

Leroux-Dhuys, J.-Fr. 1998. Cistercian Abbeys. Cologne.

LUB III. 1857. Liv-, Esth- und Curländisches Urkundenbuch nebst Regesten. Bd. III.

Raam, V. 1958. Padise klooster. Tallinn.

Raam, V. 1969. Padise kloostri varemetes 1968. a. hooajal toimunud kaevamistööde aruanne. Manuscript in the National Heritage Board. Tallinn.

Raam, V. 1970. Aruanne 1969. aastal Padise kloostri varemeis toimunud uurimistöödest. Manuscript in the National Heritage Board. Tallinn.

Raam, V. 1992. Paadisten luostari. - Helsingin pitäjä, 44-54.

Raam, V. 1997. Padise klooster. - Eesti arhitektuur, III. Tallinn, 43-44.

Schmidt, W. 1941. Die Zisterzienser im Baltikum und in Finnland. (Suomen Kirkkohistoriallisen Seuran Vuosikirja, 1939-1940, XXIX-XXX.) Helsinki.

Schneider, A., Wienand, A., Bickel, W. \& Coester, E. 1977. Die Cistercienser. Geschichte Geist - Kunst. Köln.

Tamm, J. 2002. Eesti keskaegsed kloostrid. Tallinn.

Tuulse, A. 1942. Die Burgen in Estland und Lettland. (Verhandlungen der Gelehrten Estnischen Gesellschaft, XXXIII.) Dorpat.

\section{Villu Kadakas}

\section{SEGADUS “KABELIGA” PADISE KLOOSTRI LÕUNATIIVAS}

\section{Resümee}

Padise kloostrikompleksi ehitusliku kujunemise lugu on pälvinud rohket tähelepanu seoses 1950.-1960. aastatel toimunud konserveerimis- ja uurimistöödega. Rusude eemaldamist, mis katkes 1970. aastate algul, juhtis Villem Raam, kellelt pärineb ka praegu üldtunnustatud kontseptsioon hoonekompleksi ehituslikust kujunemisest. 1990. aastatel taaskäivitunud rusude eemaldamine lõunatiivas jätkus 2003. aasta suvel kuue šurfi kaevamisega ruumis 2 . Need uurimistööd andsid tõuke käesoleva artikli kirjutamiseks.

Padise piirkond kuulus juba 13. sajandil Daugavgrīva kloostrile. 1281. aastal asus kirjalike allikate järgi Padisel mingi kabel. Raami hüpoteesi järgi püstita- 
sid Dünamünde mungad juba 13. sajandil hilisema kloostri lõunatiiva alale Kloostri jõe kaldal kabeli, millest vastavalt hüpoteesile on säilinud müüritise alumine osa praeguste ruumide 2 ja 2 a välismüüride näol. Kloostri klausuuri rajamine ei toimunud arvatavasti enne 1305. aastat, kui Dünamünde klooster müüdi Liivi Ordule ja mungad olid sunnitud Padisele kolima. Raami järgi oli klooster algselt kavandatud kloostritele tavapärase neljakandilise siseõuega nelja tiivaga hoonekompleksina, mille lõunatiivast ulatus välja varasem kabel. Esimese (1317-1343) ja teise (1375-1425) ehitusperioodi jooksul ehitati suures osas välja neli tiiba koos kahekorruselise ristikäiguga. Kolmandal perioodil (1425-1448) lõpetati tööd lõunatiivas ja lisati läänetiiva ette laiendus koos uue väravatorniga.

Juba enne šurfide kaevamist oli mitmele välitööde juhatajat konsulteerinud spetsialistile - Kaur Alttoale, Mart Keskkülale ja Jaan Tammele - selge, et hüpotees kabelist on vähetõenäoline ja et ruumidele 2 ning 2 a tuleks otsida muud ajaloolist funktsiooni. Alttoa on pakkunud, et Daugavgrīva kloostril võis olla Padisele rajatud majandusliku funktsiooniga filiatsioon (sisuliselt majandusmõis), mille juurde võisid kuuluda ruumid 2 ja 2 a. Kabeli-hüpoteesi algseks tõukeks ja olulisimaks põhjenduseks olid ilmselt 13. sajandiga dateeritud portaali ja võlvisüsteemi raiddetailid, mis leiti 1960. aastate lõpul ruumide 2 ja 2 a rusudest. Ühtki neist ei ole aga ruumide seintest leitud ja seetõttu pole põhjust järeldada, et need kuulusid ruumide 2 ja 2 a algse dekoori hulka. Võimalik, et need detailid olid juba enne Liivi sõda mingis seinas kasutusel sekundaarse ehitusmaterjalina ja algne kabel, kus iganes see ka paiknes, võis olla selleks ajaks ammu lammutatud. Oluliseks argumendiks selle kohta, et ruumid 2 ja 2 a võiksid olla varasemast ajast kui lõunatiiva välismüür ja ilmselt kloostri terve nelja tiivaga peakorpus, on nende ruumide idaseina aknaavad, mis avanevad lõunatiiva siseruumi nr 3. Sellest vastuolust tuleb lähemalt juttu allpool.

2003. aasta välitööde käigus selgus, et ruumide 2 ja 2 a vahesein, mida varem on peetud välisseinte suhtes sekundaarseks, on ehitatud koos välisseintega. Niiviisi on moodustatud kaks täiesti identse põhiplaaniga ruumi. Ruumide kõige silmapaistvamaks tunnuseks on segment- ja ümarkaarsed nišid kõigi välisseinte siseküljel. Need ei paikne juhuslikult üksikutes kohtades, vaid on planeeritud ühe tervikliku süsteemina, nagu on märkinud Raam. Kummagi ruumi idaseina keskel kahe niši vahel on paiknenud ukseava, mis on algselt olnud nende ruumide ainsaks ühendusteeks. Ukseava vaheseinas ja kummagi ruumi lääneseina aknaavad, mis praeguseks on kõik hävinud, olid Raami andmetel samuti hilisemad läbimurded. Kummagi ruumi idaseina aknaavad on olnud seintes tõenäoliselt juba algselt.

Ruumi 2a kirdeosas on Raami andmetel paiknenud tahutud paeplaat hüpokaustahju kütteavadega ja selle all ahju võlv. Šurfist 5 ruumi 2 kaguosas leiti aastal 2003 mingi kolde jäänused, mis ilmselt seostuvad sellesama küttesüsteemiga, mis oli arvatavasti mõlema ruumi jaoks ühine. Ruumide 2 ja 2a kirjeldamisel tuleb nõustuda Raami kokkuvõttega, et ruumid on moodustanud ühtse arhitektuurilise terviku, mida on nii plaaniasetuselt kui ka ehituskunstiliselt iseloomult raske siduda kloostriansambli üldkompositsiooniga. 
Kokkuvõttes pakkusid 2003. aasta šurfid üllatava järelduse: ruumide 2 ja $2 \mathrm{a}$ ehk nn kaksikruumide seinad on püstitatud alles pärast mingi varasema kivihoonestuse lammutamist. Ruumi 2 lääneseina all on varem paiknenud muuhulgas kaks ukseava (šurfid 1 ning 2) ja ruumi edelanurgast leiti paeplaatidest põranda fragment (šurf 3), mis paiknevad oluliselt madalamal hilisema ruumi 2 põrandatasemest. Šurfis 4 paljandus ruumi 2 idaseinast varasema portaali raidkivist piit. Padise kloostri ehitusajaloolist arengut on seni kirjeldatud kui üksnes positiivsete sündmuste järgnevust, st kui üksteisele järgnevaid ehitustöid uute osade lisamisega ilma vahepealsete oluliste lammutustöödeta. Võib pidada loomulikuks, et ulatuslikke keskajal toimunud lammutustöid toovad esile eelkõige arheoloogid, sest negatiivsete stratigraafiliste ühikute kontseptsioon on tekkinud just arheoloogias. Kaksikruumidest varasema hoonestuse täpsemat iseloomu on raske määratleda. Ruum 11 on pidanud mingil kujul juba eksisteerima, kuna sinna on avanenud ukseavad. Ruumi 2 kagunurga kohal on võinud varem teoreetiliselt paikneda kloostri nelja tiivaga klausuuri kagunurk.

Juba 1960. aastate välitööde ajal selgus, et kaksikruumide idasein on klausuuri lõunatiivast püstvuugiga eraldatud. Ruumi 2 idaseina aknaavad on avanenud lõunatiiva ruumi 3 sisse. Need asjaolud olid ilmselt kriitilise tähtsusega Raami kloostrist varasema kabeli hüpoteesi tekkimisel. Neid fakte ei saa ignoreerida ka praegu, kuid neid on raske seostada uue teadmisega, et kaksikruumide rajamisele on eelnenud varasema hoonestuse lammutamine. Sellisel kujul oleks meil tegemist kaksikruumide kompleksiga, mis on rajatud pärast mingi kivihoonestuse lammutamist, kuid mis ise oleks vanem kloostri neljakandilisest klausuurist. Alttoa pakutud hüpotees kloostrieelsest majandusmõisast on täiesti ootuspärane eeldus, kuid samas on asjade sellise seisu juures põhjust kahtlustada mingit eksimust, mis on tehtud tähelepanekute ja järelduste ahelas füüsilise substantsi uurimisel.

Varem teostatud uuringute aruannete läbivaatamise puhul kahtlustab ehitusarheoloog kõigepealt seda, et mõni stratigraafiliste ühikute vaheline piirjoon võib olla jäänud tähele panemata, st et mingisugused kaks ühikut on jäänud eristamata. Teiste sõnadega: on põhjust kahtlustada, et hoone ehitusajaloo uurimisel on mingi teoreetiline kontseptsioon mänginud suuremat rolli kui füüsilise substantsi üksikasjalik väliuurimine. Antud küsimuses pälvib kõigepealt tähelepanu suurim ehitusosa - kloostri neljakandilise klausuuri välismüür. Ei ole põhjust kahelda selles, et ringmüüri alumine, keldri ja põhikorruse osa, on põhimõtteliselt rajatud korraga ühe etapi käigus. Mitmete ebakorrapärasustega ülejäänud ringmüüri suhtes paistab silma lõunatiiva ringmüüri läänepoolne osa, mis on ühtlasi ruumi 3 lõunaseinaks. Siin näiteks katkeb ida- ning lõunatiiva siseküljel jälgitav ümarkaarsete niššide rütm ja müür on teise korruse osas ülejäänud välismüürist tunduvalt õhem. Lõunatiiva edelanurk, mis on ühtlasi ruumi 3 esimese ja teise korruse edelanurgaks, on erinevalt klausuuri ülejäänud tahutud kividest nurkadest laotud tahumata kividest.

Nende ja mõne muu tähelepaneku põhjal võib oletada, et lõunatiiva välismüür on ruumi 3 kohal mingil ajal suures osas uuendatud, muutes täielikult selle varasema ilme. Järelikult on võimalik, et see, mis ulatub ruumide 2 ja 2 a idaseinani, 
ei ole mitte algne välismüür, vaid mingi hilisem müüritis. Seega on mõeldav, et klausuuri välismüür pole algselt kaksikruumide idaseinani ulatunudki ja ka ruumi 3 polnud siis veel olemas. See omakorda vihjab võimalusele, et ruumi 3 kohal on kunagi paiknenud läbipääs ehk väravakäik. See seletaks aknaavade olemasolu ruumi 2 idaseinas.

Vaadeldes kloostrikompleksi asendiplaani, torkab silma, et kloostri erinevate etappide välismüür ulatub jõeni või vallikraavini nii põhja-, lääne- kui edelaküljel. Idakülje kohta pole andmeid. Vaid lõunaküljel paikneb vallikraavi serv klausuuri lounatiivast minimaalselt seitsme meetri kaugusel, jättes kloostriehitiste ja kraavi serva vahele kohati üle kümne meetri laiuse platoo. Seletuse platoole annaks väravakäik lõunatiivas ruumi 3 kohal. Põhimõtteliselt analoogse paigutusega on algselt olnud ka läänevärav, mille ette on hiljem püstitatud eeslinnus koos uue väravatorniga. Sellisel viisil oleks väravakäik otserünnaku eest kaitstud.

Kuna lääneküljel oli värav olemas, siis tuleb püüda vastata ka küsimusele, milleks oli vajalik teine, lõunapoolne värav või väljapääs. Tavaliselt paikneb tsistertslaste kloostrites üks väljapääs idatiivas munkade jaoks, kuid Padisel pole seda kindlusliku iseloomu tõttu teadaolevalt olnud. Selle väljapääsu funktsiooni võis täita värav lõunaküljel. See ei pruukinud olla üldse nii lai, vankriga läbipääsetav ja langevõrega varustatud nagu läänevärav, vaid väike, inimestele mõeldud väljapääs. Kloostri lõunaküljel oleks sobiv koht jõe paisutamiseks, et täita idapoolne vallikraav veega. Seega võis sealkandis paikneda vesiveski. Tuleb meenutada, et seni pole teada ka keskaegse maantee ja silla ning kloostri sadama asukoht. Kloostri lõunaküljel on võimalik spekuleerida mööduva maantee ja silla asukohaga, mis võimaldanuks kloostril liiklust paremini kontrollida ja piiramise korral silda enda valduses hoida. Lõunavärav võis kaotada oma funktsiooni koos idapoolse eeslinnuse rajamisega, mis võis tingida selle sulgemise.

Erinevalt tüüpilisest tsistertslaste kloostrist oli Padise kompaktseks kokkusurutud kindlus, mille puhul olid kompromissid ordu ehitusreeglitega paratamatud. Tüüpiliselt paiknes lõunatiivas kaks refektooriumi, üks munkade, teine ilmikvendade jaoks, risti lõunapoolse ristikäiguga. Ruumid 2 ja 2a moodustavad Padisel ainsa selliselt paikneva hooneosa, millest on lihtne järeldada, et nende ruumide peal, põhikorrusel, paiknes refektoorium. Sellest ruumist ei ole midagi säilinud. Raam on tõlgendanud suurt piklikku ruumi klausuuri kagunurgas munkade refektooriumina ilmselt seetõttu, et ruumide 2 ja 2a kohale oli ta juba varem mõelnud kabeli. See suur ruum sobiks oma asukoha järgi munkade nn päevaseks ruumiks, mis paiknes tüüpiliselt klausuuri kagunurgas. Laiad segmentkaarsed aknaavad selle ruumi lõunaseinas on pakkunud ilmselt parimat valgustust kogu klausuuris, toetades eelmainitud oletust, sest munkade nn päevane ruum oli just see koht, kus tavaliselt toimus käsikirjade kopeerimine.

Ma ei otsiks Padise kloostri ruumide hulgas spetsiifiliselt ilmikvendade jaoks kavandatud refektooriumi, mis tüüpiliselt paiknes klausuuri edelanurgas pikliku ruumina risti lõunaristikäiguga. 14. sajandiks oli ilmikvendade hulk tsistertslaste kloostrites oluliselt vähenenud ja hiliskeskajal oli tavaline, et endistele ilmikvendade ruumidele anti uus funktsioon. Seetõttu võis ruumide 2 ja 2 a peal paiknenud ruum 
olla pigem munkade refektoorium, kuna ilmikute refektooriumi kui suure ruumi järele puudus ilmselt vajadus. Väheste ilmikvendade söögiruumina võidi kasutada mõnd väiksemat ruumi läänetiivas. Läänetiiva silmatorkavalt väikesed mõõtmed Padisel osutavad arvatavasti ilmikvendade vähesele osatähtsusele selles kloostris. Läänetiiva peakorrusel, vahetult ruumist 2 põhja pool, paiknes arvatavasti köök.

Padise klausuuri keldriruumid on kõik lihtsa väljanägemisega ja on olnud ilmselt kasutusel erinevate majandusruumidena. Vaid kabel kiriku idaosa all ja ruumid 2 ning 2 a on keldrikorrusel esinduslikud, mistõttu võiks oletada muud funktsiooni. Ruumide 2 ja 2 a küttesüsteem osutab elufunktsioonile. Lõunavärava olemasolu või puudumine ei muuda asjaolu, et kloostri põhikompleksi rajamise järel pääses ruumi 2 klausuuri seest ja ruumi $2 a$ klausuurist väljastpoolt. Kõige tähelepanuväärsem on ruumi 2a tagasihoidliku, eriliste kaitseelementideta ukseava paigutamine kloostri põhiterritooriumist väljapoole. Väravakäigu läheduse tõttu võiks oletada, et ruumidesse majutati näiteks kloostri väravavalvur. Kuna lõunapoolne väravakäik oleks viinud klausuuri sisemisele, vaid munkadele mõeldud alale, siis oleks väravavalvuri asupaigaks sobinud pigem läänevärav või hiljem eeslinnuse värav, kui see juba eksisteeris.

Samas osutab kahe identse ruumi põhimõtteline paigutus kloostri klausuuri suhtes, üks sees- ja teine väljaspool, keerulisema ideoloogia rakendamisele. Kaks ruumi tunduvad olevat identse funktsiooniga, pole aga samal ajal "võrdselt" paigutatud. Padise kloostri ruumijaotuse olemasolev kontseptsioon ei hõlma külalistemaja või külalistele mõeldud ruume, mis ometi pidid kusagil paiknema. Tüüpiliselt paiknes külalistemaja, mis oli igas tsistertslaste kloostris kindlasti olemas, klausuurist võimalikult kaugel kloostri välisvärava läheduses. Padise kloostri kindluslik iseloom võis tingida ka selles küsimuses erandi, pakkudes vähemalt tähtsamatele külalistele ööbimisvõimalust kloostri kindlustatud osas. Kaks ruumi sobiksid hästi kõrgete külaliste majutamiseks. Sisemine ruum 2 võis olla ette nähtud vaimuliku (näiteks piiskop või emakloostri abt) ja välimine ruum 2a ilmaliku külalise jaoks. Niiviisi oleks mõne tähtsama sündmuse puhul olnud võimalik pakkuda võrdset teenindust korraga nii ilmalikule kui vaimulikule Padise kloostri isandale. Ilmalik isand oleks niiviisi majutatud väljapoole munkade territooriumi kokkuleppelist piiri, mis võis kulgeda piki lõunatiiva välisseina joont. Samas oleks olnud võimalik mõlemaid kõrgeid külalisi ühtviisi teenindada ja nad oleksid püsinud teatavas mõttes võrdses staatuses. Loomulikult võib siin ka muid seletusi olla.

Ruumide 2 ning 2 a ja oletatava lõunatiiva värava kohta on andmeid liiga vähe, et kirjutada absoluutsetest dateeringutest. Julgen oletada, et ruumid 2 ning $2 \mathrm{a}$ on ehitatud kloostri perioodil ja mitte hiljem. Oletatav värav võidi sulgeda ka hiljem, näiteks Liivi sõja aegsete kindlustustööde käigus. Tüüpiline väliuuring tekitab rohkem uusi küsimusi, kui see jõuab vastata vanadele, nii ka 2003. aasta uuringud Padisel. Loodetavasti annavad tulevased väliuuringud vastuse mitmele probleemile, kaasa arvatud väravakäigu kunagine olemasolu lõunatiivas. Paljud küsitavused, näiteks kaksikruumide kunagine funktsioon, ei selgu ilmselt kunagi, vaid jäävadki diskussiooniobjektiks. 